\title{
Studies Regarding Identification and Assessment of Noise Generating Sources in Different Areas of Work
}

\author{
Mariana Ciobanu' ${ }^{a^{*}}$, Ionela Bucse ${ }^{1, b}$, Cristian Ghermec ${ }^{1, c}$ \\ ${ }^{1}$ University of Craiova, Faculty of Mechanics, Department of Engineering and Management of \\ Technological Systems, Drobeta Turnu Severin, Romania, www.imst.ro \\ amaryana_ciobanu@yahoo.com, bucse_ionela@yahoo.com, ccristian_ghermec@yahoo.com
}

Keywords: noise, professional deafness, stress, hearing loss, assessment of noise

\begin{abstract}
Occupational noise is a complex of sounds of different levels and pitches, with different characteristics (impulsive, pure, audible), rhythmic or nonrhythmic, produced continuously by machines, instruments, devices or discontinuously by vehicles, human voice, during occupational activity. Noise problem is more complex and from this point of view things are far from being good. "Vladimir Spilda, Commissary for Social Affairs and Egual Chances: Noise effects are not limited only to lossing hearing, He can be causing workplace accidents and increasing stress level." Noise can be source of risk of workplace accidents, work-related stress and combined with other risk factors at the work place can damage health in both the long and short term.
\end{abstract}

\section{Introduction}

„The silence of the dead; noise took power everywhere; is the only ecological disaster for which no one seems to worry." Alain Finkielkraut

Noise in one of the physical environmental factors affecting our health in today's world. Noise in generally defined as the unpleasant sounds which disturb the human being physically and physiologically and cause environmental pollution by destroying environmental properties [10].

Professional deafness in the EU is very important among admitted professional diseases and consequently, it engenders high costs. For these reasons, protection against noise is stipulated as an essential request in the European Council's Directive no. 89/106/CEE [3, 12, 13].

The noise becomes a main risk in occupational hearing loss and deafness when it exceeds the daily threshold limit value of $87 \mathrm{~dB}(\mathrm{~A})$, legal in our country [9].

\section{Materials and experimental procedure}

The two important components of noise are the frequency, measured in Hertz (Hz) and intensity, measured in decibels $\mathrm{dB}(\mathrm{A})$.

Intensity ( sound pressure level ) measured in Bell ( commonly subunits $\mathrm{dB}$ ) .

Home size acoustic used to characterize the acoustic field sound pressure level L, defined by the relationship:

$\mathrm{L}[\mathrm{dB}]=20 \log \frac{p}{p_{0}}$

$\mathrm{p}_{0}=210^{-5}=20 \mu \mathrm{Pa}$

$\mathrm{p}$ - instantaneous sound pressure

$\mathrm{p}_{0}$-reference pressure

Weighted sound pressure level A:

$\mathrm{L}_{\mathrm{A}}[\mathrm{dB}(\mathrm{A})]=20 \log \frac{p_{A}}{p_{0}}$ 
Sound request a certain period is characterized by the equivalent continuous sound pressure level LAeq, $\mathrm{T}$ :

$L_{\text {Aeq, } T}=\frac{1}{t_{2}-t_{1}} 10 \int_{t_{1}}^{t_{2}}\left(\frac{p_{A}}{p_{0}}\right)^{2} \cdot d t$

Measurements were made with the meter Bruel \& Kjaer. Analyzer Bruel \& Kjaer latest type 2250 is designed advanced applications of determining, analyzing and recording noise and vibration.

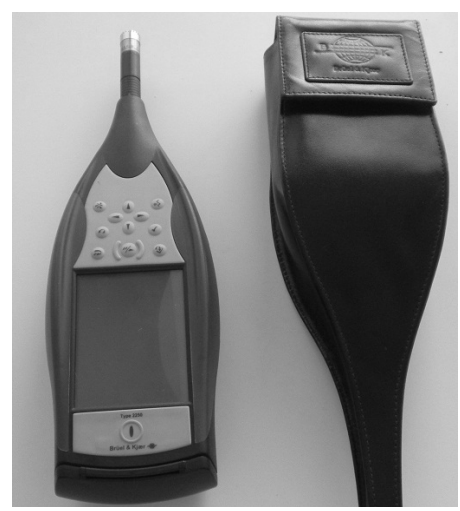

Fig.1 Analyzer Bruel \& Kjaer latest type 2250

Measurements were made in various fields of economic activities, identifying and evaluating noise values specific industrial installations.

Table 1 Measurements of noise in various fields of economic activities

\begin{tabular}{|l|c|c|}
\hline No. & Field of activity & Noise value measured \\
\hline 1. & inside the car painting - painting & $89,29 \mathrm{~dB}$ \\
\hline 2. & inside winding machines - mechanical & $100 \mathrm{~dB}$ \\
\hline & & \\
\hline
\end{tabular}




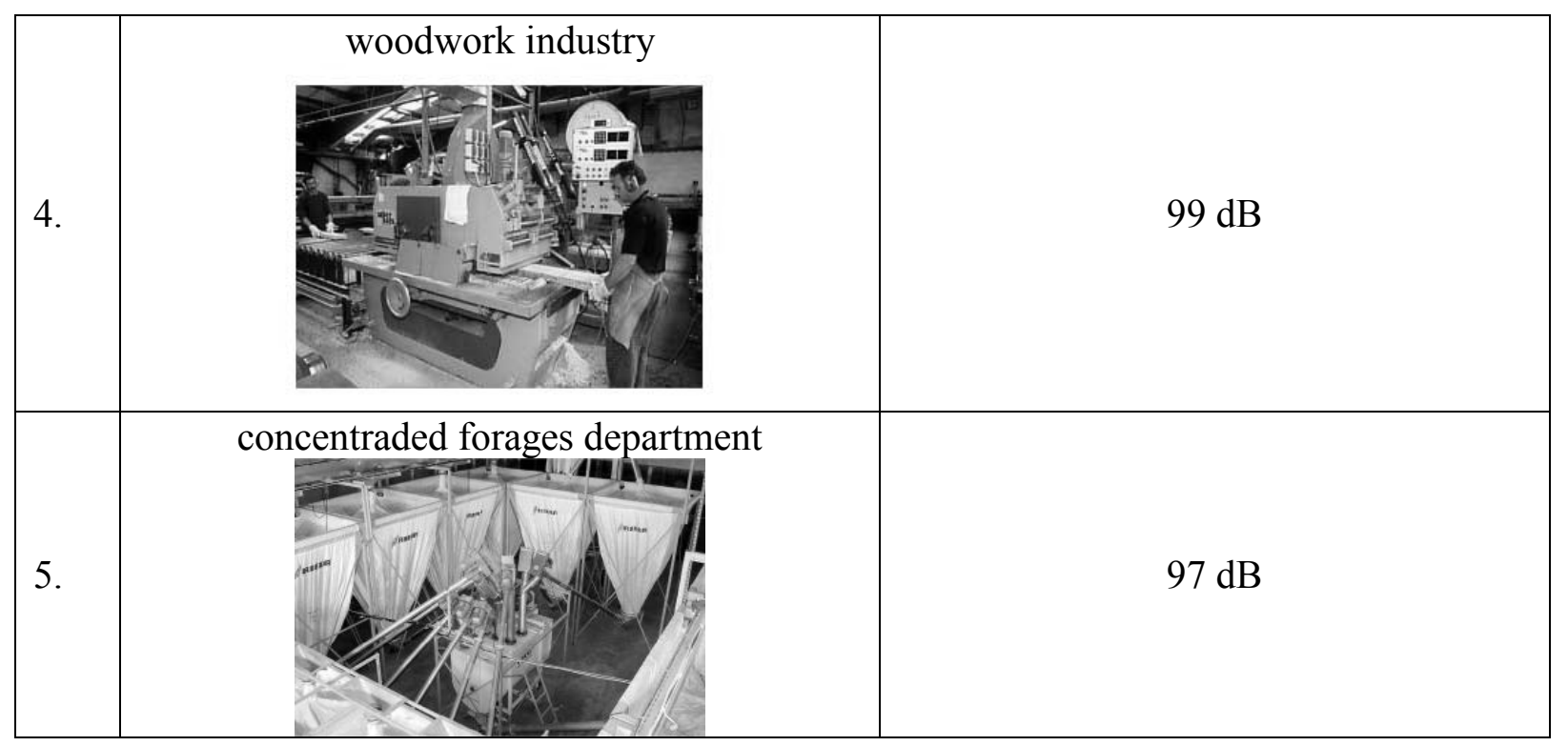

Maximum tolerable intensity is around $100 \mathrm{~dB}$, but it varies depending on the frequency.

In the industry area the sound can has the origin like: pneumatical; mechanical (metal-on-metal impacts, separation vibrating machine panels etc.); electrical (close the electrical switch, magnetical circuit noise at the power station); hydraulical (flow, pump aspiration); aerial (ventilation, blowing);

Woodwork industry. Noise emission is due to circular saws, milling cutters, heads of the moulder machines, vidia cutters of the shaping machines, wood borers and other tools and devices for wood processing with high rotation speed (3000 rot/min or higher).

Noise is one of the main noxa agents in the woodwork industry and thus its importance is often brought forward in health and safety laws and regulations. Basically it can cause hearing loss (or deafness). Beside this disease, workers' long exposure to noise without taking into account the health and safety requirements can lead to a wide range of affections: accentuating the muscles reflexes -stress; affections of the central nervous systems; growth of the gastric secretion; hypoglycemia; weight loss; sight loss; concentration capacity loss; attention deficit; working capacity loss leading to accidents.[8]

Concentraded forages department has specific endowments: machines, installations and industrial equipment, electical devices and specific automation process.

We found the workplaces wich are probable more expoused to noise as a professional insult:

- Graining machines - workplace occupied by maitenance electrician and engine attendant which is taken care of the graining machines. Exposure to noise is permanently during the $12 \mathrm{~h}$ shift

- Salt supply - workplace occupied by an worker who supplyed with salt taking into account electrical measuring.Noise exposure is periodical,of approximated $6-7 \mathrm{~h} /$ day during the $12 \mathrm{~h}$ shift

- Mills and Classification mills- flow sheet components were are not workplaces, but were noise is high and affect other workplaces from inside and outside.

\section{Results and discussions}

The occupational exposure to noise is determined by history of occupational exposure, proved with official documents stating the years of work in exposure to noise and with measurements of noise level at work place. The inquiry also establishes the type of PPE (earphones) and collective protection (phonoabsorbant booths, phonoabsorbant materials).[9]

Noise need not be excessively loud to cause problems in the workplace. Noise can interact with other workplace hazards to increase risks to workers by, for example:

- Increasing the risk of accidents by masking warning signals;

- Interacting with exposure to some chemicals to further increase the risk of hearing loss; or

- Being a causal factor in work-related stress. 
Exposure to noise may pose a variety of health and safety risks to workers:

- Hearing loss: Excessive noise damages the hair cells in the cochlea, part of the inner ear, leading to loss of hearing. "In many countries, noise-induced hearing loss is the most prevalent irreversible industrial disease [5]. It is estimated that the number of people in Europe with hearing difficulties is more than the population of France [6].

- Physiological effects: There is evidence that exposure to noise has an effect on the cardiovascular system resulting in the release of catecholamines and an increase in blood pressure. Levels of catecholamines in blood are associated with stress.

- Work-related stress: Work-related stress rarely has a single cause, and usually arises from an interaction of several risk factors. Noise in the work environment can be a stressor, even at quite low levels.

- Increased risk of accidents: High noise levels make it difficult for staff to hear and communicate, increasing the probability of accidents. Work-related stress (in which noise may be a factor) can compound this problem [7].

\section{Conclusions}

Elimination or diminution of noise in the work place is a company responsibility and should be done not just because it is required by law. Noise diminution at the source should be seen as the most important part of noise control activity (planning, maintenance of equipment) [1,2].

For machines and installations considered dangerous from the point of view of noise exposure, measurements were performed by authorized institutions and the noise level was established by technical certificates issued for each objective and each area where the risk factor had been identified.[4]

Noise reduction measures can be very expensive, but the safer and the healthier the work environment, the lower the probability of problems like absenteeism, accidents and lack of efficiency that can be as expensive [8].

Employers are obliged to keep control and check periodically if the existing precaution for the noise control and diminution are adequate, and work efficiently.

The quality of workers' life suffering from irreversible hearing loss due to occupational noise exposure over the TLV is diminished and those affected by it are "condemned" to a communication impaired life [4].

The only treatment for hearing loss is prevention through technical-administrative measures of reducing noise.

The health and safety of noise exposed worker is nowadays a priority [10].

\section{References}

[1] Mihaela Amalia Tîrniceanu, "Poluarea sonoră", Scientific meeting - "Hidroenergetica şi protecţia mediului" ( 2001).

[2] Mihaela Amalia Tîrniceanu, "Zgomote şi vibraţii - poluare sonoră", Scientific meeting 2002 "Protecţia mediului".

[3] Olimpia Ghermec, Research regarding the possibility to reduce the phonetic pollution of residential quarters bordering industrial areas, Bulletin of the Polytechnic Institute of Iasi, Tomul LV (LIX), Fasc.3, 2009.

[4] Hans-Horst Konkolewsky, directorul AESSM, interview.

[5] Liviu Dâmboiu, The reduction of noise exposure, an important issue in the management Strategy of S.C. Drumco S.A., "European Weekfor Safety And Health At Work", 24-28.october.2015.

[6] World Health Organisation: prevention of noise-induced hearing loss, 1997.

[7] SIHI study group at The University of Maastricht, 1999. 
[8]***https://osha.europa.eu/en/topics/noise/problems_noise_cause_html Accessed: 2014-07-20

[9] Ioan Gherman, "Introducing technical and organizational measures for noise control in Deko Rame Ltd., a wood processing company", "European Weekfor Safety And Health At Work", 24-28 october 2015.

[10] Adriana Todea, Aurelia Ferencz, Occupational morbidity due to noise exposure in Romania, Occupational Health Department-Institute of Public Health, Romania, November $22^{\text {nd }} 2005$. [11]*** http://www.pjoes.com/pdf/14.6/721-726.pdf

[12] Ghermec, O., Ghermec, C, Forming eco-responsible behavior of future engineers based on the study of carbon footprint, Hidraulica, No. 2/2014, p. 39-43, ISSN: 1453 - 7303.

[13] Ghermec, O., Ghermec, C, Research regarding the reduction of the greenhouse gases emissions in the academic laboratories; case studies, Ecoterra - Journal of Environmental Research and Protection, 2013, no. 37, p. 61-65, ISSN: 2248-3128. 